\title{
EFEKTIFITAS PENGGUNAAN MEDIA ELMANTAB TERHADAP HASIL BELAJAR ILMU PENGETAHUAN ALAM
}

\author{
Url Jurnal: https://uia.e-journal.id/akademika/article/1338 \\ DOI : https://doi.org/10.34005/akademika.v10i01.1338
}

Submitted: 2021-04-24

\author{
Khasanah \\ Universitas Islam As-Syafi'iyah- \\ Indonesia \\ Khasanahrcl.mtp@uia.ac.id
}

Reviewed: 2021-05-11

\author{
Deden Marjuki \\ Madrasah Ibtidaiyah Terpadu Al \\ Hamid-Indonesia \\ dedenmarjuki09@gmail.com
}

Published: 2021-05-30

\author{
Nursanita Nasution \\ Universitas Islam As-Syafi'iyah- \\ Indonesia \\ Nursanitanasution.mtp@uia.ac.id
}

\begin{abstract}
This study aims to describe the application and effectiveness of the use of Elmantab media in Natural Sciences subjects in grade IV of Al Hamid Integrated Islamic Madrasah. Elmantab media is an application developed independently by the Mantab Al Hamid Foundation, which is located at Jalan Cilangkap Baru, Cilangkap Kelurahan, Cipayung District, East Jakarta City. This online-based learning application is a paid application to the relevant provider. This type of research is qualitative. The problems in this study are clearly described in the results of the research obtained based on the facts obtained in the field. The data collection techniques used consisted of observation, interview (interview), questionnaire and documentation. The research subjects were the school principal, science teacher at grade IV and 106 grade IV students at the Al Hamid Integrated Madrasah Ibtidaiyah in the 2020/2021 school year. Data analysis using triangulation techniques methods and data sources. This study also uses MillesDuberman analysis techniques through the stages of reduction, exposure to data and drawing conclusions. The results showed that the use of Elmantab was declared effective in the distance learning process. The learning outcomes of students in the Natural Sciences subject get excellent grades. Evidenced by documentation and the results of interviews with class IV science teachers. The average score obtained was 87.36 for the cognitive aspects and the average score was 86.26 for the psychomotor aspects. As for the percentage of student learning completeness both cognitive and psychomotor $92.07 \%$ and $97.02 \%$. The percentage of student learning completeness in both cognitive and psychomotor aspects was $92.07 \%$ and $97.02 \%$.
\end{abstract}

Keywords: elmantab media, learning effectiveness, science learning

\begin{abstract}
Abstrak: Penelitian ini bertujuan untuk mendeskripsikan penerapan dan efektivitas penggunaan media Elmantab pada mata pelajaran IImu Pengetahuan Alam di kelas IV Madrasah Ibtidaiyah Terpadu Al Hamid. Media Elmantab adalah aplikasi yang dikembangkan secara mandiri oleh Yayasan Mantab Al Hamid yang beralamat di Jalan Cilangkap Baru Kelurahan Cilangkap Kecamatan Cipayung Kota Jakarta Timur. Aplikasi pembelajaran berbasis online ini adalah aplikasi berbayar pada provider yang terkait. Penelitian ini jenisnya adalah kualitatif. Masalah dalam penelitian ini di gambarkan dengan jelas dalam hasil penelitian yang didapatkan berdasarkan fakta-fakta yang didapatkan di lapangan. Teknik pengumpulan data yang digunakan terdiri dari observasi, interview (wawancara), angket dan dokumentasi. Subjek penelitian adalah Kepala Sekolah, Guru mata pelajaran IPA pada jenjang kelas IV dan 106 orang siswa kelas IV di Madrasah Ibtidaiyah Terpadu Al Hamid tahun pelajaran 2020/2021. Analisis data menggunakan teknik triangulasi metode dan sumber data. Penelitian ini juga menggunakan teknik analisis Milles-Duberman melalui tahap reduksi, paparan data dan
\end{abstract}


penarikan kesimpulan. Hasil penelitian menunjukkan bahwa Penggunaan Elmantab dinyatakan efektif pada proses pembelajaran jarak jauh. Hasil belajar siswa mata pelajaran IImu Pengetahuan Alam mendapatkan nilai yang baik sekali. Dibuktikan dengan dokumentasi dan hasil wawancara dengan guru mata pelajaran IPA kelas IV. Nilai rata-rata yang diperoleh adalah 87,36 untuk aspek kognitif dan nilai rata-rata 86,26 untuk aspek psikomotorik. Adapun prosentase ketuntasan belajar siswa aspek kognitif maupun psikomotoriknya adalah 92,07 \% dan 97,02\%.

Kata Kunci : media elmantab, efektifitas pembelajaran, pembelajaran IPA

\section{PENDAHULUAN}

Perkembangan teknologi informasi dan komunikasi yang sangat cepat pada saat ini dan menawarkan banyak kemudahan bagi manusia dalam memperoleh informasi. Pemenuhan kebutuhan beberapa informasi yang kita perlukan menjadi begitu mudah dan cepat diperoleh dengan hadirnya jaringan internet. Salah satu manfaat hadirnya teknologi internet dalam bidang pendidikan adalah sebagai sarana pembelajaran. Sarana pembelajaran berbasis teknologi menjadi sangat penting dan relevan saat ini, karena pada suasana pandemi Covid-19 (Corona Virus Deseases) yang melanda dunia. Proses belajar mengajar tidak diperboleh untuk bertemu dengan tatap muka secara langsung, namun harus melalui jaringan atau media pembelajaran berbasis online. Proses belajar mengajar melalui daring ini merupakan solusi saat pandemi ini karena dalam upaya mencegah penyebaran virus corona yang lebih luas dan lebih parah.

Selama pembelajaran di masa pandemi ini guru mengalami kesulitan dalam proses kegiatan belajar mengajar, karena sangat beragam media dan metode belajar yang digunakan selama pembelajaran jarak jauh (PJJ) yang dimulai pada awal penyebaran pandemi covid-19 awal maret sampai bulan Juni 2020. Database atau data penyimpanan baik berupa materi bahan ajar dan hasilhasil penilaian harian atau tugas yang disudah diberikan sulit untuk didokumentasikan atau diarsipkan. Guru dan orangtua mengalami kesulitan dalam penyampaian materi Ilmu Pengetahuan Alam, karena melalui proses pembelajaran daring dan orangtua masih banyak yang kurang paham dengan materi pelajaran IImu Pengetahuan Alam. Guru kesulitan dalam memantau kehadiran dan keaktifan siswa dalam kegiatan pembelajaran jarak jauh (PJJ). Orangtua siswa mengalami kesulitan memantau hasil-hasil tugas yang telah dikerjakan oleh siswa secara langsung. Hasil belajar siswa mata pelajaran IImu Pengetahuan Alam pada semester genap tahun pelajaran 2019-2020 yang terlihat dalam kegiatan Penilaian Akhir Semester (PAS) Genap yang belum maksimal dengan rata-rata 80,07. Belum maksimalnya hasil belajar siswa menjadikan Yayasan Mantap Al-Hamid yang menaungi sekolah ini mengembangkan media Elmantab, berharap mendapatkan suatu solusi untuk perbaikan hasil belajar. Yayasan Mantab Al Hamid yang beralamat di Jalan Cilangkap Baru Kelurahan Cilangkap Kecamatan Cipayung Kota Jakarta Timur. Media Elmantab adalah aplikasi yang dikembangkan secara mandiri.

Aplikasi pembelajaran berbasis online ini adalah aplikasi berbayar pada provider yang terkait. Aplikasi media Elmantab ini dimunculkan pada awal tahun pelajaran 2020-2021 dan telah diresmikan penggunaannya oleh Kepala Bidang 
Pendidikan Madrasah Kanwil Kementerian Agama Provinsi DKI Jakarta. Aplikasi Elmantab ini, memberikan kemudahan bagi guru dan peserta didik untuk pelaksanaan kegiatan pembelajaran jarak jauh (PJJ) di lingkungan unit pendidikan di bawah naungan Yayasan Mantab Al Hamid.

Aplikasi Elmantab yang baru dikembangkan ini menjadikan kami sebagai peneliti ingin meneliti sejauh mana efektifitas media ini. Beberapa pertanyaan terkait adalah Bagaimana penerapan penggunaan Media Elmantab dan bagaimanakah efektivitas penggunaan media E-Learning Elmantab. Adapun untuk mata pelajaran dibatasi mata pelajaran IImu Pengetahuan Alam dan kelas yang diteliti adalah kelas 4 Madrasah Ibtidaiyah. Tujuan penelitian ini adalah untuk mendeskripsikan penerapan penggunaan media Elmantab dan mendeskripsikan efektivitas penggunaan media Elmantab terhadap hasil belajar pada mata pelajaran IImu Pengetahuan Alam di Madrasah Ibtidaiyah Terpadu Al Hamid.

Beberapa media online lain telah dikembangkan dan digunakan secara massif, seperti google Clasroom, moodle, ruang guru, Quizizz. Dimana sudah banyak para peneliti telah melakukan penelitian terkait media tersebut. Penelitian yang terkait dengan moodle yaitu Hasil penelitian pada mata pelajaran prakarya dan kewirausahaan yang diajar menggunakan media e-learning berbasis moodle dimana hasil belajar menggunakan media e-learning Moodle lebih tinggi hasil belajarnya dari pada siswa yang diajar menggunakan media cetak (Musa \& Khasanah, 2019).

Penelitian terdahulu lainnya menyatakan terdapat perbedaan yang signifikan hasil belajar akuntansi antara siswa yang diajar menggunakan strategi pembelajaran e-learning dengan siswa yang diajar menggunakan strategi ekspositori. Hasil belajar akuntansi yang di ajar menggunakan strategi pembelajaran e-learning lebih tinggi dari pada siswa yang di ajar menggunakan strategi ekspositori (Kristiyani \& Budiningsih, 2019).

Demikian juga penelitian pada jenjang lebih tinggi yaitu di perguruan tinggi, menunjukkan bahwa mahasiswa siap menghadapi aturan baru the new normal live apabila dilaksanakan perkuliahan secara luring. Sedangkan untuk sistem perkuliahan yang efektif selama pandemi adalah daring dan luring secara bergantian dengan memperhatikan prinsip protokol pencegahan Covid-19

Tiga temuan di atas menunjukkan bahwa media pembelajaran online di masa Covid-19 ini adalah sesuatu yang seharusnya di gunakan dengan maksimal, dimasa pembelajaran jarak jauh ini, sudah selayaknya mencari format pilihan media yang tepat digunakan di sekolah dan Lembaga Pendidikan lainnya. Salah satu media yang telah dikembangkan dimasa covid ini adalah media Elmantab. Sangat dibutuhkan media yang bisa menfasilitasi adanya jarak antara siswa dan guru.tinjauan efektifitas media Elmantab ini perlu dikaji agar apakah tepat penggunaan media ini di sekolah. Bahkan dapat dijadikan media untuk lembaga pendidikan lainnya.

Memperjelas tentang makna Efektifitas dan indikatornya, akan kita lakukan kajian teoritis terhadap Efektifitas ini. Efektifitas menurut Ravianto (2014:11) adalah seberapa baik pekerjaan yang dilakukan, sejauh mana orang menghasilkan keluaran sesuai dengan yang diharapkan. Dikatakan Efektif apabila suatu pekerjaan dapat diselesaikan sesuai dengan perencanaan, baik dalam waktu, biaya, maupun mutunya maka dapat dikatakan efektif. Pengertian lain menurut Othenk, efektivitas adalah pemanfaatan sumber daya, sarana dan 
prasarana dalam jumlah tertentu yang secara sadar ditetapkan sebelumnya untuk menghasilkan sejumlah barang atas jasa kegiatan yang dijalankannya (Othenk,2008:4). Efektivitas menunjukkan keberhasilan dari segi tercapai tidaknya sasaran yang telah ditetapkan. Jika hasil kegiatan semakin mendekati sasaran, berarti makin tinggi efektivitasnya.

Sementara jika dikaitkan dengan pemebelajaran maka efektifitas pembelajaran terjadi manakala adanya interaksi edukatif yang terjadi, yaitu interaksi yang sadar akan tujuan. Interaksi ini berakar dari pihak pendidik (guru) dan kegiatan belajar secara pedagogis pada diri peserta didik, berproses secara sistematis melalui tahap rancangan, pelaksanaan, dan evaluasi. Pembelajaran tidak terjadi seketika, melainkan berproses melalui tahapan-tahapan tertentu. Dalam pembelajaran, pendidik menfasilitasi peserta didik agar dapat belajar dengan baik. Dengan adanya interaksi tersebut maka akan menghasilkan proses pembelajaran yang efektif sebagaimana yang telah diharapkan (Hanafy, 2009 :74).

Tujuan pembelajaran adalah faktor yang sangat penting dalam proses pembelajaran. Dengan adanya tujuan, maka guru memiliki pedoman dan sasaraan yang akan dicapai dalam kegiatan mengajar. Apabila tujuan pembelajaran sudah jelas dan tegas, maka langkah dan kegiatan pembelajaran akan lebih terarah. Tujuan dalam pembelajaran yang telah dirumuskan hendaknya disesuaikan dengan ketersediaan waktu, sarana prasarana dan kesiapan peserta didik. Sehubungan dengan hal itu, maka seluruh kegiatan guru dan peserta didik harus diarahkan pada tercapainya tujuan yang telah diharapkan (Nata, 2009 : 314).

Jika dilihat dari sisi ruang lingkupnya, tujuan pembelajaran dapat dibagi menjadi dua bagian, yaitu:(1)Tujuan yang dirumuskan secara spesifik oleh guru berasal dari materi pelajaran yang akan disampaikan, (2)Tujuan Pembelajaran Umum, yaitu tujuan pembelajaran yang sudah tercantum dalam garis-garis besar pedoman pengajaran yang dituangkan dalam rencana pengajaran yang disiapkan oleh guru. Tujuan khusus yang dirumuskan oleh seorang guru harus memenuhi syarat-syarat, yaitu: (a)Secara spesifik menyatakan perilaku yang akan dicapai, (b)Membatasi dalam keadaan mana pengetahuan perilaku diharapkan dapat terjadi (kondisi perubahan perilaku), (3)Secara spesifik menyatakan kriteria perubahan perilaku dalam arti menggambarkan standar minimal perilaku yang diterima sebagai hasil yang dicapai (Nata, 2009 : 315)

Pembelajaran yang efektif dapat didefinisikan sebagai pembelajaran yang berhasil mencapai tujuan belajar peserta didik sebagaimana yang diharapkan oleh guru (Kyriacou 2009:29). Sedikitnya ada dua unsur pokok dalam pembelajaran yang efektif, yaitu (a) guru harus memiliki suatu gagasan jelas tentang tujuan belajar yang diharapkan (b) pengalaman belajar yang direncanakan dan disampaikan dapat tercapai.

Bistari Basuni Yusuf dalam penelitiannya yang berjudul konsep dan indikator pembelajaran yang efektif (Yusuf, $2017: 19)$ menyimpulkan bahwa ada lima indikator pembelajaran yang efektif yaitu pengelolaan pelaksanaan pembelajaran, proses komunikatif, respon peserta didik, aktifitas mengajar dan hasil belajar. Kelima indikator tersebut saling terkait 
dan mendukung. Pembelajaran dikatakan efektif bila semua indikator dimaksud mencapai minimal kategori baik.

Untuk mata pelajaran IImu Pengetahuan Alam di tingkat dasar kelas 4 ada beberapa kompetensi dasar sebagai indikator yang harus dimiliki atau dipahami oleh siswa, yaitu berdasarkan Peraturan Menteri Pendidikan dan Kebudayaan Nomor 24 Tahun 2016 tentang Kompetensi Inti dan Kompetenasi Dasar Pelajaran pada Kurikulum 2013. Sehingga dapat disimpulkan bahwa yang dimaksud dengan efektifitas pembelajaran IImu Pengetahuan Alam adalah pembelajaran yang berhasil mencapai tujuan yang didasarkan pada kompetensi-kompetensi dasar yang terdapat pada mata pelajaran IImu Pengetahuan Alam.

Pembelajaran di masa Covid ini menunutut adanya penggunaan E-Learning dalam proses pembelajaran, sehingga jarak ini tidak menjadi alasan tidak dilaksanakannya pembelajaran. Munir (2009 :169) menyatakan bahwa istilah E-Learning dapat pula didefinisikan sebagai sebuah bentuk teknologi informasi yang diterapkan di bidang pendidikan dalam bentuk dunia maya. E-Learning menurut Stokley merupakan merupakan sarana pembelajaran yang dilakukan dengan memanfaatkan teknologi seperti internet, intranet, CD Room, dan cd. Dalam hal ini teknologi jaringan digunakan untuk menyampaikan isi atau materi pembelajaran kepada siswa. Menurut Rosenberg bahwa E-Learning adalah pemanfaatan teknologi internet untuk menyampaikan dan memperkaya pengetahuan dan kinerja atau performa penggunanya. $E$ Learning sebagai pengajaran dan pembelajaran yang menggunakan rangkaian elektronik (LAN, WAN, atau internet) untuk menyampaikan isi pembelajaran, interaksi, atau bimbingan (Koran, 2002 :20). Adapun menurut Hartley (2001) menjelaskan bahwa E-Learning merupakan suatu jenis belajar mengajar yang memungkinkan tersampaikannya bahan ajar ke siswa dengan menggunakan media internet, atau media jaringan komputer lain.

Dalam pelaksanaan kegiatan pembelajaran melalui daring. Secara umum terdapat beberapa hal penting sebagai persyaratan pelaksanaan E-Learning (Mada Wena, 2009:212) yaitu (a)Kegiatan proses pembelajaran dilakukan melalui pemanfaatan jaringan, (b)Tersedianya dukungan layanan tutor yang dapat membantu siswa apabila mengalami kesulitan belajar, (c)Adanya lembaga penyelenggara/pengelola ELearning, (d)Adanya sikap positif dari siswa dan tenaga pendidik terhadap teknologi komputer dan internet, (e) Tersedianya rancangan sistem pembelajaran yang dapat dipelajari, (f) Adanya sistem evaluasi terhadap kemajuan belajar siswa dan mekanisme umpan balik yang dikembangkan oleh lembaga penyelenggara. Dari beberapa persyaratan tersebut tentang pelaksanaan E-Learning, maka harus dipenuhi dan dilengkapi sehingga proses pembelajaran melalui jaringan internet ini dapat berjalan dengan lancar dan efektif.

Aplikasi media Elmantab memungkinkan terjadinya proses pengadministrasian bahan pembelajaran, baik berupa modul, penugasan, penilaian dan evaluasi pembelajaran itu sendiri. Siswa dapat melihat secara terbuka bahan pembelajaran tersebut dengan menggunakan bantuan internet 
sebagai penghubung antara siswa dan guru. Oleh karena itu media Elmantab ini dapat dikatakan sebagai media E-Learning. Media Elmantab adalah aplikasi yang dikembangkan secara mandiri oleh Yayasan Mantab Al Hamid yang beralamat di Jalan Cilangkap Baru Kelurahan Cilangkap Kecamatan Cipayung Kota Jakarta Timur. Aplikasi pembelajaran berbasis online ini adalah aplikasi berbayar pada provider yang terkait. Aplikasi media E-Learning Elmantab ini dimunculkan pada awal tahun pelajaran 2020-2021 dan telah diresmikan penggunaannya oleh Kepala Bidang Pendidikan Madrasah Kanwil Kementerian Agama Provinsi DKI Jakarta. Aplikasi Elmantab ini dibuat dalam rangka memberikan kemudahan bagi guru dan peserta didik untuk pelaksanaan kegiatan pembelajaran jarak jauh (PJJ) di lingkungan unit pendidikan di bawah naungan Yayasan Mantab Al Hamid. Dan aplikasi Elmantab ini juga memudahkan bagi orang tua dalam memonitoring kegiatan pembelajaran jarak jauh yang dilakukan oleh putra-putrinya di rumah.

Aplikasi media E-Learning Elmantab ini memiliki beberapa fitur login yang digunakan pada masing-masing, baik untuk login guru maupun login siswa. Untuk memasuki aplikasi tersebut baik guru maupun siswa masing-masing harus login ke aplikasi dengan menginput username dan password yang diberikan oleh Tim Ahli IT. Menu konten yang tersedia dari aplikasi tersebut terdapat perbedaan, yaitu yang terdapat di menu login guru dengan menu yang terdapat di login siswa.

Fitur menu dalam aplikasi E-Learning Elmantab terdiri dari 11 menu. (1) Dashboard yang berisi biodata atau profil guru yang berisi nama lengkap, NIP atau NUPTK, tempat tanggal lahir, jenis kelamin, nomor handphone, alamat rumah, jabatan, alamat website, username dan password. Dalam menu ini ada kotak edit yang berfungsi merubah atau mengganti jika ada yang salah dalam biodata guru. (2) Manajemen kelas yaitu berisi tentang kelas berapa saja yang guru ajarkan seuai dengan surat tugas mengajarnya dan data siswa dari kelas. (3) Mata pelajaran yaitu berisi tentang mata pelajaran yang diajarkan oleh guru sesuai dengan surat tugas yang diberikan. Pada menu ini terdapat kode mapel, nama mata pelajaran dan kelas. (4) Materi yaitu untuk mengirimkan bahan materi pelajaran kepada siswa sesuai dengan pelajaran yang diajarkan. Guru dapat mengupload bahan materi yang berupa file PDF, gambar atau video pembelajaran, link sumber lain yaitu mengkoneksikan dengan video dari youtube atau link video lainnya. (5) Manajemen tugas dan penilaian yaitu menu yang berkaitan dengan tugas yang dikerjakan siswa terdiri dari Latihan/Kuis, Penilaian Harian, Penilaian Tengah Semester dan Penilaian Akhir Semester. (6) Laporan penilaian berisi laporan nilai dari siswa yang sudah selesai mengerjakan penugasannya. (7) Tugas portofolio berupa tugas berbentuk hasil karya siswa baik berupa gambar atau video. (8) Berita yaitu menu yang berisi tentang berita atau informasi penting tentang pembelajaran jarak jauh yang dilakukan. (9) Forum diskusi yaitu tempat untuk berdiskusi bagi guru dan siswa. Guru menambahkan materi berupa file pdf atau video, lalu siswa dapat langsung berkomentar dan guru menjawab komentar atau pertanyaan dari siswa. (10) Google meet yaitu aplikasi yang terkoneksi dengan aplikasi Elmantab dalam rangka melakukan pertemuan tatap muka secara online melalui aplikasi tersebut. Pembelajaran dapat dilakukan secara langsung dengan virtual antara guru dan siswa dapat berkomunikasi, menyampaian materi pelajaran dan memberikan tanya jawab. Untuk menggunakan aplikasi terkoneksi google meet ini guru harus membuat kode meeting dan link kode meeting tersebut selanjutnya dibagikan ke 
siswa atau orang tua melalui whatsapp atau media lainnya. (11) Rekapitulasi absensi siswa yaitu menu untuk menyatakan kehadiran siswa pada setiap hari jadwal pembelajaran. Hal ini memberikan motivasi siswa untuk memulai pembelajaran jarak jauh.

Berdasarkan kajian di atas maka peneliti tertarik untuk melakukan penelitian tentang "Efektifitas Penggunaan Aplikasi E-Learning Elmantab Pada Mata Pelajaran IImu Pengetahuan Alam Madrasah Ibtidaiyah Terpadu Al Hamid". Adapun yang menjadi masalahnya adalah : (1) Bagaimanakah penerapan penggunaan media $E$ Learning Elmantab pada mata pelajaran Ilmu Pengetahuan Alam di Madrasah Ibtidaiyah Terpadu Al Hamid? (2) Apakah efektif penggunaan media E-Learning Elmantab pada mata pelajaran Ilmu Pengetahuan Alam di Madrasah Ibtidaiyah Terpadu Al Hamid?

\section{METODE}

Penelitian ini bertujuan untuk mendeskripsikan masalah yang terjadi apa adanya di lapangan. Oleh karena itu pendekatan yang digunakan adalah kualitatif deskriptif. Penggambaran keadaan subyek atau objek penelitian pada saat tersebut berdasarkan fakta-fakta yang terlihat. Teknik pengumpulan data yang digunakan terdiri dari observasi, interview (wawancara), angket dan dokumentasi. Subjek penelitian terdiri dari Kepala Sekolah, Guru mata pelajaran IPA pada jenjang kelas IV dan 106 orang siswa kelas IV di Madrasah Ibtidaiyah Terpadu Al Hamid tahun pelajaran 2020/2021.

Analisis data menggunakan teknik Triangulasi data untuk mengecek kebenaran data yang diperoleh dari berbagai sudut pandang yang berbeda. Caranya dengan mengurangi sebanyak mungkin bias yang terjadi pada saat pengumpulan dan analisis data. Menurut Norman K. Denkin triangulasi merupakan kombinasi berbagai metode untuk mengkaji fenomena yang saling terkait dari perspektif yang berbeda. Triangulasi yang digunakan dalam penelitian ini adalah triangulasi sumber data dan metode, Data berdasarkan hasil wawancara, angket, dokumentasi dan observasi. Sumber data berasal dari kepala sekolah, guru dan siswa.

Penelitian ini juga menggunakan teknik analisis Milles-Duberman yang terdiri dari tiga tahap yaitu (1) reduksi, (2) paparan data, dan (3) penarikan kesimpulan. Reduksi adalah proses pemilihan data yang relevan, penting, bermakna, dan data yang tidak berguna untuk menjelaskan sasaran analisis dengan membuat jalan fokus, klasifikasi, dan abstraksi data kasar menjadi data yang bermakna untuk dianalisis. Paparan data adalah proses menguraikan data yang telah direduksi. Penarikan kesimpulan adalah membuat ringkasan dari penjelasan mengenai data dengan poin-poin yang penting.

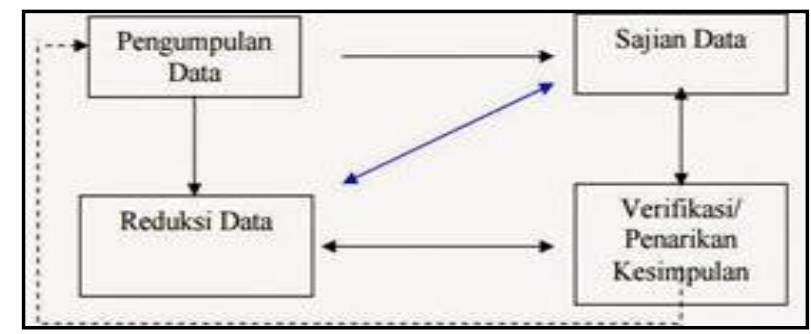

Gambar 5. Teknik Analisa Data Menurut Milles dan Hubberman 
Pada tahap akhir penelitian ini mengambil kesimpulan berdasarkan langkah-langkah yang sudah dilakukan meliputi data observasi dan dokumentasi arsip terhadap perbedaan hasil telah diperoleh sebelum dan meningkat sesudah melakukan penelitian. Untuk mempermudah menganalisa data dari observasi dan angket, maka digunakan rumus prosentase sebagai berikut :

$$
P=\frac{F}{N} \times 100 \%
$$

Dapat diterangkan dari rumus di atas bahwa $\mathrm{P}$ adalah Prosentasi yang di cari. $\mathrm{F}$ adalah Nilai yang diperoleh setiap siswa. $\mathrm{N}$ adalah Nilai tertinggi ( skala nilai raport). 100 adalah Bilangan tetap. Rumus persentase tersebut membantu untuk mendiskripsikan tingkat efektifitas penggunaan media Elmantab dengan melihat hasil belajar sebelum dan setelah penggunaan media ini.

\section{HASIL}

Adapun hasil data pengamatan siswa terhadap guru dalam melaksanakan proses pembelajaran mata pelajaran Imu Pengetahuan Alam (IPA) yang dimulai dari proses tahap persiapan pembelajaran, tahap pelaksanaan, dan tahap penutupan dapat dijelaskan sebagai berikut:

\section{Persiapan Pembelajaran}

Pada tahap persiapan pembelajaran secara prosentase sudah baik, karena memperoleh prosentase di atas $90 \%$. Artinya persiapan pembelajaran yang akan dilaksanakan guru sudah sangat baik. Adapun kegiatan persiapan pembelajaran tersebut terdiri dari memberikan semangat belajar, mengingatkan pelajaran sebelumnya, mengucapkan salam dan mengabsensi kehadiran siswa, memotivasi untuk bertanya, mengamati gambar dan menjelaskan materi yang berhubungan dengan gambar tersebut. Dapat disimpulkan bahwa secara umum proses tahapan persiapan pembelajaran yang dilakukan oleh guru pada mata pelajaran IPA kelas 4 dikatakan sudah sangat baik.

\section{Pelaksanaan Pembelajaran}

Pada tahap pelaksanaan pembelajaran beberapa kegiatan telah mendapatkan prosentase di atas 90\%, sangat baik. Adapaun kegiatan yang dilakasanakan guru meliputi penjelasan tujuan pembelajaran, penjelasan langkah-langkah kegiatan pembelajaran. semenatara siswa menyimak dan mengamati gambar materi yang dijelaskan oleh guru, dan siswa mampu menyebutkan contoh-contoh terhadap materi yang telah disampaikan.

Adapun yang masih perlu diperbaiki adalah kemauan dan keberanian siswa untuk bertanya terhadap materi yang disampaikan guru. Adapun setelah diprosentasekan berada pada tataran 71,29 \%. Demikian juga siswa masih lemah dalam menyimpulkan materi-materi yang telah disampaikan oleh guru. 
Berdasarkan data tersebut di atas, maka dapat disimpulkan bahwa tahapan pelaksanaan pembelajaran yang dilakukan oleh guru mata pelajaran IPA kelas 4 dapat dikatakan sudah baik, walaupun masih perlu untuk diadakan perbaikan dan peningkatan dalam hal kegiatan tanya jawab siswa, menyampaikan tujuan pembelajaran dan menyimpulkan materi pelajaran yang telah diajarkan.

\section{Penutupan Pembelajaran}

Pada tahap penutupan pembelajaran secara umum sudah baik, guru sudah melaksanakan kegiatan pada tahap ini dengan prosentase diatas $80-90 \%$. Adapun yang perlu diperbaiki adalah guru terkadang lupa untuk menyimpulkan materi yang disampaikan, guru masih belum maksimal dalam memberikan pesan-pesan moral kepada siswa dan masih kurang dalam hal pemberian pekerjaan rumah (PR) kepada siswa.

Berdasarkan hasil data di atas, maka dapat disimpulkan bahwa pada kegiatan penutupan pembelajaran yang dilakukan oleh guru mata pelajaran IImu Pengetahuan Alam (IPA) kelas 4 dapat dikatakan baik dan sangat memuaskan, walaupun masih ada catatan perbaikannya.

Selain dengan pengumpulan data melalui observasi, peneliti juga mengumpulkan data penelitian dengan pengambilan data angket yang diberikan kepada siswa terhadap penggunaan aplikasi media Elmantab dalam pelaksanaan proses pembelajaran mata pelajaran Imu Pengetahuan Alam (IPA) di kelas 4. Adapun hasil pengumpulan data angket siswa sebagaimana yang tertera dalam tabel dibawah ini.

Berdasarkan data hasil angket siswa berkaitan dengan penggunaan media Elmantab pada mata pelajaran IImu Pengetahuan Alam (IPA) di atas, maka dapat disimpulkan bahwa:

1) Dalam penggunaan media Elmantab oleh siswa kelas 4 secara prosentase melebihi $90 \%$ yaitu berkaitan dengan memahami dan mengerti langkah-langkah penggunaan aplikasi (97,03\%), memiliki sarana seperti handphone atau komputer $(99,01 \%)$, mudah memahami bahan materi pelajaran $(97,03 \%)$, mengerjakan latihan soal dan tugas sesuai dengan jadwal yang ada (95,05\%), mendapatkan bimbingan dari orang tua $(84,16 \%)$, menyelesaikan tugas protofolio yang diberikan $(99,01 \%)$, mengikuti kegiatan evaluasi pembelajaran seperti penilaian harian, penilaian tengah semester dan penilaian akhir semester dengan sungguh-sungguh, melaporkan jika ada kendala teknis di aplikasi, dan mengikuti kegiatan pembelajaran jarah jauh dengan penuh semangat dan tanggungjawab.

2) Ada beberapa hal yang perlu diperhatikan dan ditingkatkan yaitu masih kurang aktifnya siswa dalam bertanya kepada guru di aplikasi tersebut dengan prosentase sebesar $79,21 \%$, ada beberapa siswa yang masih kurang bagus jaringan internetnya sehingga kurang lancar dan mengalami kendala dalam menggunakan aplikasinya dengan prosentase sebesar $89,11 \%$, lalu masih kurangnya kemandirian siswa dalam mengerjakan tugas-tugas dengan prosentase sebanyak $71,29 \%$, selanjutnya siswa tidak melihat buku atau catatan dalam 
mengerjakan soal PH, PTS dan PAS dengan prosentase sebesar $84,16 \%$, masih lemahnya kesukaan siswa untuk membaca materi secara berulang-ulang dengan prosentase sebesar $90,1 \%$.

3) Berkaitan dengan kendala pemenuhan kuota internet dalam penggunaan aplikasi tersebut masih cukup tinggi dengan prosentase sebesar $31,68 \%$, sedangkan yang tidak terkendala kuota internet sebesar $68,32 \%$. Hal ini menjadi salah satu hal yang perlu dicarikan solusi terbaik untuk siswa dalam rangka kelancaran pembelajaran jarak jauh, karena jika tidak ada kuota internet, maka pasti terkendala proses pembelajarannya.

Berdasarkan hal tersebut di atas, maka dapat disimpulkan bahwa penggunaan media Elmantab oleh siswa dapat dikatakan sudah sangat baik. adapun masih adanya kendala dan kekurangan di beberapa hal, maka perlu diperbaiki dan dicarikan solusi terbaiknya, sehingga proses pembelajaran jarak jauh dengan aplikasi ini dapat berjalan dengan baik dan lancar.

Adapun hasil pengmatan peneliti terhadap 5 guru dalam kegiatan pembelajaran mata pelajaran IImu Pengetahuan Alam (IPA) kelas 4 dengan menggunakan aplikasi Elmantab via google meet dapat dianalisis datanya berdasarkan dari jawaban yang sama setiap point butir instrumen yang telah disediakan. Adapun Hasil pengamatan yang dimaksud adalah :

\section{Tahap kegiatan persiapan}

Pada tahap persiapan guru dengan prosentase $100 \%$ yaitu pada kegiatan mengucapkan salam dan membaca doa awal pembelajaran, mengabsensi kehadiran siswa dan menanyakan kabarnya dan menjelaskan tujuan pembelajaran atau kompetensi yang diajarkan. Adapun kegiatan mengadakan tes awal hanya prosentase $80 \%$ dan kegiatan menyiapkan fisik dengan Ice Breaking masih belum maksimal dilakukan oleh guru, karena masih hanya prosentase $60 \%$. Dan guru menjelaskan tentang langkah-langkah dari pembelajaran sebanyak $60 \%$.

\section{Tahap Kegiatan Inti}

Pada tahap kegiatan inti guru sudah melakukan hampir prosentase $100 \%$ di kegiatan ini, hanya ada satu kegiatan yang masih perlu dimaksimalkan karena prosentase 60\%. Siswa masih perlu dilatih keberanian atau tak malu untuk bertanya terhadap hal atau materi yang telah disampaikan yang perlu dijelaskan lebih dalam.

\section{Tahap Kegiatan Penutupan}

Kegiatan penutupan sudah dilaksanakan guru dengan prosentase $100 \%$. pada kegiatan mengadakan refleksi pembelajaran, mengadakan tes atau latihan soal, menjelaskan materi atau tujuan pembelajaran di pertemuan berikutnya dan mengakhiri pertemuan pembelajaran dengan membaca doa dan mengucapkan salam. Adapun hal yang masih perlu diperbaiki adalah guru belum mengadakan kegiatan mengajak siswa untuk menyimpulkan materi yang telah diajarkan dengan prosentase sebesar $60 \%$ dan masih kurang dalam memberikan pesan-pesan moral kebaikan kepada siswa dengan prosentase $60 \%$. 


\section{Hasil Belajar Siswa pada Mata Pelajaran IPA}

Hasil belajar siswa kelas 4 pada mata pelajaran IImu Pengetahuan Alam Semester Ganjil tahun pelajaran 2020-2021 ditinjau dari aspek dari dua aspek, yaitu Aspek kognitif dan psikomotorik

Hasil belajar kognitif dalam penelitian ini adalah hasil belajar yang mengarah pada kemampuan dasar pengetahuan (K3) siswa dari beberapa kompetensi dasar yang ada pada mata pelajaran IImu Pengetahuan Alam (IPA) kelas 4 dengan nilai ketuntasan minimal adalah 72. Oleh karenanya siswa yang mendapatkan nilai dibawah dari KKM (72), maka dianggap tidak tuntas dalam pembelajaran tersebut. Adapun jumlah siswa yang mendapatkan nilai di bawah KKM sebanyak 8 orang dari jumlah 101 siswa yang ada. Hasil rata-rata ketuntasan belajar mata pelajaran IImu Pengetahuan Alam sebesar 92,07\%, dengan rata-rata nilai 87,38 .

Dengan hasil prosentase hasil belajar siswa kelas 4 mata pelajaran IImu Pengetahuan pada aspek kognitif ini, maka dapat dikatakan bahwa hasil belajar siswa dengan menggunakan media Elmantab berada pada tataran baik sekali. Adapun bagi siswa yang mendapatkan hasil tidak tuntas, maka perlu diadakan perbaikan.

Hasil belajar dari aspek psikomotorik dalam penelitian ini adalah hasil belajar yang mengarah pada kemampuan dasar keterampilan (K4) siswa yang diperoleh dari data penilaian akhir semester ganjil siswa kelas 4 pada mata pelajaran IImu Pengetahuan Alam. Pada aspek psikomotorik ini prosentase ketuntasan belajar sebesar $97,02 \%$ dengan rata-rata nilai 86,26 yaitu baik sekali. Adapun bagi siswa yang masih belum tuntas dalam hasil belajar mata pelajaran IImu Pengetahuan Alam, harus tetap melaksanakan perbaikan atau remedial pada kompetensi dasar yang belum dipahami.

Berdasarkan hasil belajar nilai rata-rata dan prosentase ketuntasan belajar siswa pada mata pelajara IImu Pengetahuan Alam dalam aspek kognitif maupun aspek psikomotorik adalah baik sekali. Dapat dikatakan bahwa siswa kelas 4 Madrasah Ibtidaiyah Terpadu Al Hamid mendapatkan hasil yang sangat baik dan sangat memuaskan.

\section{PEMBAHASAN}

Penggunaan media Elmantab dalam proses pembelajaran sudah sangat baik dan tepat, dimana guru telah melakukan persiapan pembelajaran dengan baik, melaksanakan kegiatan inti dan menutup pembelajaran dengan baik sekali. Hal ini berdasarkan hasil amatan siswa dan peneliti sendiri saat berlangsungnya pembelajaran dengan menggunakan media interaktif google meet. Semua bahan pembelajaran telah disiapkan dalam media Elmantab, demikian juga dengan soal-soal evaluasi hasil pembelajaran yang dilaksakan sebelum dan setelah dilaksanakannya pembelajaran. Administrasi pembelajaran yang baik oleh guru sangat mendukung hasil belajar yang baik. Hal ini sejalan dengan 
temuan lain yang menyatakan bahwa penerapan e-learning berbantuan media pembelajaran edmsodo berpengaruh terhadap hasil belajar siswa, terlihat perbedaan yang signifikan pada hasil belajar siswa sebelum dan sesudah penerapan. Nilai rata-rata hasil belajar yang diperoleh pada posttest adalah 64 sedangkan nilai rata-rata pada pretest adalah 17 artinya nilai posttest lebih tinggi dibandingkan nilai pretest sehingga terjadi peningkatan hasil belajar (Podungge et al., 2020).

Dalam media Elmantab ini juga dapat dilihat hasil pretest dan postest siswa, karena sudah disipakan dengan baik oleh guru. Adapun hasil belajar IPA siswa mendapatkan nilai rata-rata 86,26 dan prosentase ketuntasan belajar sebesar 97,02 \% yaitu baik sekali. Dapat dikatakan bahwa sasaran dan tujuan yang direncanakan dalam pembelajaran tersebut dapat tercapai. Dengan demikian maka dapat dikatakan pembelajaran dengan menggunakan media Elmantab dinyatakan sangat efektif. Temuan dalam penelitian ini yang menyatakan bahwa media Elmantab efektif digunakan dalam pembelajaran di masa covid-19 dan dapat di perluas penggunaannya untuk Lembaga Pendidikan lainnya. Hal ini seperti yang dinyatakan oleh Daryanto (2013:32-33) Pembuatan media adalah sangat penting, karena dengan perencanaan yang baik dalam membuat produk media pembelajaran berbasis e-learning yang dihasilkan akan memiliki tingkat kemanfaatan yang sesuai dengan tingkat kemampuan siswa, hal ini diungkapakn dalam Budiman et al., (2019).

Temuan ini di dukung oleh Hakim yang menyatakan bahwa media harus dapat menjangkau seluruh peserta didik dan menjadi solusi alternatif terhadap kurangnya semangat belajar peserta didik. Salah satu media yang tepat yaitu dengan menggunakan media berbasis Augmented Reality (AR) Melaui Augmented Reality, guru dapat membuat media pembelajaran yang menyenangkan, interaktif, dan mudah digunakan. Augmented Reality juga dapat menggantikan modul pembelajaran yang belum ada di sekolah dalam bentuk virtual atau maya (Hakim, 2018).

Menurut Emerson Handayaningrat (1985:35) bahwa pengertian efektifitas adalah pengukuran dalam arti tercapainya sasaran atau tujuan yang telah ditentukan sebelumnya. Dalam kegiatan pembelajaran, maka tujuan yang ingin dicapai diukur melalui evaluasi yang dilakukan. Hasil ini menunjukkan bahwa penggunaan media Elmantap dalam pembelajaran IPA sangat efektif meningkatkan hasil belajar IPA. Dan direkomendasikan untuk dilanjutkan, bahkan sekolah-sekolah dapat menggunakan media ini.

Evaluasi adalah penerapan berbagai cara dan penggunaan dari beragam alat penilaian untuk memperoleh informasi tentang sejauh mana hasil belajar peserta didik atau ketercapaian kompetensi (kemampuan) peserta didik.

Penilaian menjawab pertanyaan tentang sebaik apa hasil atau prestasi belajar seorang peserta didik. Pentingnya penilaian akhir siswa dengan berbagai teknik/aspek juga dapat melihat efektifitas media. Sebagaimana yang diungkapkan Setiadi bahwa Teknik penilaian yang digunakan dalam proses pembelajaran yaitu (1) penilaian kompetensi 
sikap melalui observasi, penilaian diri, penilaian teman sejawat dan jurnal; (2) penilaian kompetensi pengetahuan melalui tes tertulis, tes lisan dan penugasan; (3) penilaian kompetensi keterampilan melalui tes praktik, projek dan portofolio. Peng gunaan teknik penilaian disesuaikan dengan kebutuhan-kebutuhan yang dapat menunjang program pengajaran (Setiadi, 2016)

Hasil penilaian dapat berupa nilai kualitatif (pernyataan naratif dalam kata-kata) dan nilai kuantitatif (berupa angka).

\section{KESIMPULAN}

Berdasarkan pada hasil penelitian dan analisis pembahasan berkaitan dengan efektifitas penggunaan media E-Learning Elmantab terhadap hasil belajar siswa kelas 4 pada mata pelajaran IImu Pengetahuan Alam, maka dapat diambil kesimpulan sebagai berikut: Penggunaan media E-Learning elmantab dinyatakan efektif pada proses pembelajaran jarak jauh, hal ini dikarenakan pada tahapan proses pembelajaran guru mulai dari tahap perencanaan, pelaksanaan dan evaluasi dijalankan sesuai dengan ketentuan yang ada.

Penggunan media E-Learning elmantab ini juga tidak mengalami kendala yang signifikan dari segi teknis yang menunjang kelancaran pembelajaran jarak jauh seperti sinyal jaringan internet kuat yang digunakan siswa dengan prosentase sebesar $89,11 \%$, dan yang masih terkendala sebesar $10,89 \%$. Adapun yang berkaitan dengan pemenuhan kuota internet yaitu sebesar $68,32 \%$ yang tidak terkendala dan yang masih terkendala sebesar $31,68 \%$

Hasil belajar siswa mata pelajaran IImu Pengetahuan Alam mendapatkan nilai yang cukup memuaskan, hal ini dapat dibuktikan dengan dokumentasi dan hasil wawancara dengan guru mata pelajaran IPA tersebut dengan rata-rata nilai 87,36 untuk aspek kognitif dan nilai rata-rata sebesar 86,26 untuk aspek psikomotorik. Adapun prosentase ketuntasan belajar siswa baik dalam aspek kognitif maupun psikomotorik dalam pembelajaran IImu Pengetahuan Alam sebesar 92,07 \% dan 97,02 $\%$.

\section{SARAN}

Berdasarkan beberapa temuan dan analisis dari hasil penelitian tentang penggunaan media E-Learning Elmantab, maka dapat diberikan saran dan masukan yaitu Aplikasi E-Learning Elmantab masih terus perlu dikembangkan dan dilengkapi dengan menu atau fitur-fitur yang dapat memberikan kemudahan bagi guru dalam pengarsipan administrasi guru, baik berkaitan dengan materi bahan pembelajaran ataupun data-data penilaian siswa.

Aplikasi E-Learning Elmantab masih perlu diperbaiki terhadap hal yang masih menjadi kendala dalam aplikasi tersebut, dan belum bisa ditemukan solusi yang diberikan. Hal ini untuk meminimalisir mendapatkan 
keluhan dari orang tua atau siswa.

Perlu dicarikan solusi berkaitan dengan pemenuhan kuota internet yang digunakan oleh siswa untuk pembelajaran jarak jauh ini, karena masih cukup besar prosentase siswa yang masih mendapatkan kendala dalam hal tersebut.

\section{DAFTAR PUSTAKA}

Budiman, A., Arifin, A., \& Marlianto, F. (2019). Pengembangan Media Pembelajaran Berbasis E-Learning Pada SMK di Pontianak. Jurnal Nasional Komputasi Dan Teknologi Informasi (JNKTI), 2(2), 133. https://doi.org/10.32672/jnkti.v2i2.1556.

Djamarah, Syaiful Bahri \& Aswan Zain.(2006). Strategi Belajar Mengajar, Rineka Cipta, Jakarta.

Gagne, R.M. (1985). The Condition of Learning. New York: Holt, Rinehart And Winstone.

Hakim, L. (2018). Pengembangan Media Pembelajaran Pai Berbasis

Augmented Reality. Lentera Pendidikan : Jurnal IImu Tarbiyah Dan

Keguruan, 21(1), 59-72. https://doi.org/10.24252/lp.2018v21n1i6

Hanafy, Sain (2014). Konsep Belajar dan Pembelajaran. Jurnal Pendidikan. Lentera Pendidikan.

Hanum, Numiek Sulistyo, (2013).keefektian E-Learning sebagai media pembelajaran (studi evaluasi model pembelaran E-learning MK Telom Sandhy Putra Purwoketo. Jurnal Pendidikan Vokasi.

Iqbal, Muhammad (2015) Peranan Aplikasi Soal Quiz Moodle Dengan Sistem Elearning Pada Studi Kasus Di Universitas Telkom. Prosiding Saintiks FTIK Unikom.

Ismawati, Dwi, dkk (2021), Efektifitas Pembelajaran menggunakan Video Zoom Cloud pada anak usia dini Era Pandemi Covid-19. Jurnal Obsesi : Jurnal Pendidikan Anak Usia Dini.

Kristiyani, E., \& Budiningsih, I. (2019). Pengaruh Strategi Pembelajaran ELearning Dan Minat Belajar Terhadap Hasil Belajar Akuntansi. Akademika, 8(01), 81-100. https://doi.org/10.34005/akademika.v8i01.341

Munir. (2009). Pembelajaran Jarak Jauh Berbasis Teknologi Informasi Dan Komunikasi. Alfabeta, Bandung.

NA, M., \& M. Pd, K. (2019). Pengaruh Penggunaan Media E-Learning Berbasis Moodle Dan Minat Belajar Terhadap Hasil Belajar Prakarya Dan

Kewirausahaan. Akademika, 8(01), 1-16. https://doi.org/10.34005/akademika.v8i01.332

Nazarudin.(2007).Manajemen Pembelajaran: Implementasi Konsep, Karakteristik, dan Metodologi Pendidikan Agama Islam di Sekolah Umum. Teras, Yogyakarta.

Nata, Abudin. (2009). Perspektif Islam tentang Strategi Pembelajaran. Kencana, Jakarta.

Nu'man, Ahmad Zain (2014), Efektifitas Penerapan E-Learning Model Edmodo Dalam Pembelajaran Pendidikan Agama Islam Terhadap Hasil Belajar Siswa. Duta.com. ISSN : 2086-9436. 
Peraturan Menteri Pendidikan dan Kebudayaan Nomor 24 Tahun 2016 tentang Kompetensi Inti dan Kompetenasi Dasar Pelajaran pada Kurikulum 2013 pada Pendidikan Dasar dan Menengah.

Podungge, N., Paramata, D. D., \& Odja, A. H. (2020). Penerapan ELearning Berbantuan Media Pembelajaran Edmodo Terhadap Hasil Belajar Siswa Pada Konsep Gejala Pemanasan Global. Konstan Jurnal Fisika Dan Pendidikan Fisika, 5(2), 77-85. https://doi.org/10.20414/konstan.v5i2.55

Pratama, Logiva Denny, dkk (2020), Efektifitas Penggunaan Media Edutaiment di Tengah Covid-19, Aksioma : Jurnal Program Studi Pendidikan Matematika.

Pribadi, B.A (2018). 21 Konsep Esensial dalam Teknologi Pendidikan. PT Dian Rakyat, Jakarta.

Septanto, Hendri. (2015). Elearning Menggunakan Edmodo Sebuah Aplikasi Pembelajaran Berbasis Web Pada Kelas Shift Di STMIK Bina Insani. Bina Insani Journal.

Setiadi, H. (2016). Pelaksanaan penilaian pada Kurikulum 2013. Jurnal Penelitian Dan Evaluasi Pendidikan, 20(2), 166-178. https://doi.org/10.21831/pep.v20i2.7173

Sudjana, Nana. (2005). Dasar-dasar proses Belajar Mengajar. Sinar Baru Algesindo, Bandung.

Sudjana, Nana \& Rivai Ahmad. (2003). Teknologi Pengajaran, Sinar Baru Algensindo, Jakarta.Trianto.(2009). Mendesain Model Pembelajaran Inovatif-Progresif. Kencana, Jakarta.

Wena, Made (2009).Strategi Pembelajaran Inovatif Kontemporer. PTPT. Bumi Aksara, Jakarta.

Widiyono, Aan. (2020). Efektifitas Perkuliahan Daring (Online) pada Mahasiswa PGSD di Saat Pandemi Covid. Jurnal Pendidikan. 8(2): 169-177. DoI: https://doi.org/10.36232/pendidikan.v8i2.458.

Yusuf, Bistari Basuni ( 2017), Konsep dan Indikator Pembelajaran Efektif, Jurnal Kajian Pembelajaran dan Keilmuan. 